Article

\title{
Astaxanthin Inhibits Mitochondrial Permeability Transition Pore Opening in Rat Heart Mitochondria
}

\author{
Yulia Baburina ${ }^{1}$, Roman Krestinin ${ }^{1,2}$, Irina Odinokova ${ }^{1}$, Linda Sotnikova ${ }^{1}$, Alexey Kruglov ${ }^{1}[0$ \\ and Olga Krestinina ${ }^{1,2, *}$ \\ 1 Laboratory of Pharmacological Regulation of Cell Resistance, Institute of Theoretical and Experimental \\ Biophysics, Russian Academy of Sciences, Moscow Region, 142290 Pushchino, Russia; byul@rambler.ru (Y.B.); \\ rkrestinin@bk.ru (R.K.); odinokova@rambler.ru (I.O.); linda_sotnikova@mail.ru (L.S.); krugalex@rambler.ru (A.K.) \\ 2 Department of Biophysics and Medicobiological Sciences, Pushchino State Natural Science Institute, \\ Moscow Region, 142290 Pushchino, Russia \\ * Correspondence: ovkres@mail.ru
}

Received: 22 October 2019; Accepted: 20 November 2019; Published: 21 November 2019

check for updates

\begin{abstract}
The mitochondrion is the main organelle of oxidative stress in cells. Increased permeability of the inner mitochondrial membrane is a key phenomenon in cell death. Changes in membrane permeability result from the opening of the mitochondrial permeability transition pore (mPTP), a large-conductance channel that forms after the overload of mitochondria with $\mathrm{Ca}^{2+}$ or in response to oxidative stress. The ketocarotenoid astaxanthin (AST) is a potent antioxidant that is capable of maintaining the integrity of mitochondria by preventing oxidative stress. In the present work, the effect of AST on the functioning of mPTP was studied. It was found that AST was able to inhibit the opening of MPTP, slowing down the swelling of mitochondria by both direct addition to mitochondria and administration. AST treatment changed the level of mPTP regulatory proteins in isolated rat heart mitochondria. Consequently, AST can protect mitochondria from changes in the induced permeability of the inner membrane. AST inhibited serine/threonine protein kinase B (Akt)/cAMP-responsive element-binding protein (CREB) signaling pathways in mitochondria, which led to the prevention of $\mathrm{mPTP}$ opening. Since AST improves the resistance of rat heart mitochondria to $\mathrm{Ca}^{2+}$-dependent stress, it can be assumed that after further studies, this antioxidant will be considered an effective tool for improving the functioning of the heart muscle in general under normal and medical conditions.
\end{abstract}

Keywords: mitochondria; permeability transition; non-specific pore; regulatory proteins of mPTP; cell signaling; astaxantin (AST) administration

\section{Introduction}

Mitochondrial dysfunction is a cause of various diseases, including neurodegenerative and cardiovascular diseases, diabetes, different forms of damage to the liver and the skeletal and muscle systems, sepsis, and psychiatric disorders [1]. Oxidative stress and impairment of $\mathrm{Ca}^{2+}$ homeostasis are considered to be important factors in mitochondrial dysfunction, which results in the development of programmed cell death [2]. Disturbances in the functional states of mitochondria are also observed during the development of myocardial infarction, the most commonly encountered ischemic heart disease in the world, a cause of premature death in humans [3]. Mitochondria play a key role in the physiological function of the heart, and in the pathogenesis and progression of various heart diseases. Stores of mitochondrial ATP usually correlate with changes in ATP uptake by the heart, largely mediated through $\mathrm{Ca}^{2+}$ transport pathways [4]. Mitochondrial $\mathrm{Ca}^{2+}$ plays an important role in the generation of reactive oxygen species (ROS) and the opening of mitochondrial permeability transition pore (mPTP), factors involved in the development of both ischemia/reperfusion and heart failure [4-6]. A nonspecific increase in the permeability of the inner 
membrane, which leads to the formation of MPTP in mitochondria, may be the cause of mitochondrial dysfunction and cell death. The composition of pore is not yet clearly established; therefore, by convention, the supposed structural components of $\mathrm{MPTP}$ are considered to be pore regulators. Among these are the voltage-dependent anion channel (VDAC) and the translocation protein (TSPO), which are localized in the outer mitochondrial membrane; adenine nucleotide translocase (ANT) of the inner membrane; cyclophilin $\mathrm{D}(\mathrm{CyP}-\mathrm{D})$ and the phosphate carrier in the matrix; creatine kinase, localized in the intermembrane space; and hexokinase, localized in the cytosol [6]. We previously detected a protein in nonsynaptic, purified mitochondria from rat brains, which was identified as $2^{\prime}, 3^{\prime}$-cyclic nucleotide- $3^{\prime}$-phosphodiesterase (CNPase). CNPase is a myelin protein, which is also found in non-myelin-forming tissues [7-9]. We have shown that CNPase participates in the regulation of mPTP opening. Moreover, CNPase is colocalized with CyP-D, VDAC, ANT, and $\alpha$-tubulin [8]. Subunit $c$, the mitochondrial $(N, N$-dicyclohexylcarbodiimide (DCCD)-binding proteolipid [10], also known as subunit $9 \mathrm{~F}_{0} \mathrm{c}$, forms in cooperation with subunit $a$, the proton channel of $\mathrm{F}_{\mathrm{o}} \mathrm{F}_{1}$-ATPase [11]. In mammals, subunit $c$ of $\mathrm{F}_{\mathrm{o}} \mathrm{F}_{1}$-ATP synthase has three isoforms (P1, P2, and P3), encoded by ATP5G1, ATPG2, and ATPG3 genes [12]. Recently, we showed that subunit c of $\mathrm{F}_{\mathrm{O}} \mathrm{F}_{1}$-ATPase might be a structural and/or regulatory component of the mPTP complex, whose activity might be modulated by calcium-dependent phosphorylation [13].

Alterations in mitochondrial bioenergetics play important roles in the origin and progression of myocardial ischemia [14], manifesting as inhibition of respiratory complex activity, increased proton leakage from the inner mitochondrial membrane [15], increased ROS production [16], mitochondrial calcium overload [17], and finally, opening of mPTP [18]. During the development of myocardial ischemia, oxygen deprivation alters mitochondrial function and ATP synthesis, causing an important reduction in cardiac ATP production [19]. Because calcium regulation requires ATP and mPTP remains open as ATP pools dissipate, calcium levels in the ischemic heart are further elevated [18]. In addition to $\mathrm{Ca}^{2+}$ elevation, ROS production is also increased in the ischemic heart [20]. Thus, the ischemic heart is primed for a prolonged mPTP opening cycle that ultimately leads to cardiomyocyte death [20]. Ischemic conditioning as cardioprotection is believed to prevent mPTP opening at reperfusion by modulating factors known in MPTP opening, such as cellular energetic status, mitochondrial $\mathrm{Ca}^{2+}$ overloading, ROS production, and rapid $\mathrm{pH}$ correction either directly or indirectly via known cardioprotective signaling pathways. The identification of the molecular pore of the mPTP should provide further insight into unravelling the signaling pathway involved in inhibition of MPTP and further enhance the translatability of mPTP inhibition to the clinical setting [21]. mPTP has become an obvious target for cardioprotection. Drugs that inhibit mPTP directly can be of great importance in protecting the heart during heart surgery or in the treatment of coronary thrombosis.

To reduce both oxidative damage and the development of various heart diseases, considerable attention has been recently focused on studies aimed at enhancing the protective response of the organism to oxidative stress using different antioxidants. Of some interest among antioxidants is astaxanthin (AST). AST is a red pigment that belongs to xanthophylls, a subclass of carotenoids. AST possesses strong antioxidant capacity and can absorb singlet oxygens and free radicals [22]. It is found in algae, yeasts, and sea animals, such as salmon, trout, common shrimp, and lobster. Structurally, an AST molecule represents a long polyene skeleton with polar ionone rings at the ends. As a result of long-term coupling, AST responds to reduction by free radicals, and the presence of polar hydroxyl and carbonyl-containing ionone rings endows it with higher antioxidant capacity compared with other carotenoids [23]. Owing to the polar-nonpolar-polar linear structural matrix, AST can bind to the cell membrane [24]. It is also known that AST considerably attenuates the mitochondrial dysfunction associated with ischemic myocardial injury [25]. In particular, it restores the integrity of mitochondria and inhibits mitochondrion-mediated apoptosis in a model of homocysteine-induced cardiotoxicity [26].

A crucial regulatory system of signal transduction that controls many aspects of cellular functions is protein phosphorylation/dephosphorylation. One important protein kinase found in mitochondria is serine/threonine protein kinase B (Akt) [27]. The results of studies have indicated that the targets of mitochondrial Akt are complex $\mathrm{V}$ and hexokinase-II [28,29]. In addition, Akt directly affects 
mitochondria, which leads either to their protection against oxidants or to MPTP opening induced by $\mathrm{Ca}^{2+}[28,29]$. Recently, it was supposed that Akt is present in mitochondria and its level is dynamically regulated by cellular signaling activities. Within the mitochondria, Akt phosphorylates the $\beta$-subunit of ATP synthase, GSK3 $\beta$, and other unidentified proteins [30].

It is known that protein kinase A (PKA) phosphorylates cAMP-responsive element-binding protein (CREB) at Ser-133; the localization of PKA and CREB in mitochondria contributes to their possible involvement in cell survival by the regulation of mitochondrial functions through mitochondrial PKA and CREB signaling pathways [31]. Furthermore, it was shown that CREB can be phosphorylated by Akt at Ser133, leading to activation of its transcription and inhibition of apoptosis [32]. CREB plays a role in regulating the expression of some mitochondrial proteins, such as respiratory chain subunits [33], cytochrome $c$ [34], manganese superoxide dismutase [35], and carnitine palmitoyltransferase [36]. Activated CREB is able to inhibit mitochondrial activity in several cell lines and acts as a survival and differentiating factor. There is a hypothesis that CREB also plays a role in impaired mitochondrial activity [37]. Arnold and coauthors found that phosphorylated CREB induced by mitochondrial dysfunction can be considered a factor causing a defect of the cell cycle; in cells with disturbed oxidative phosphorylation, CREB activation induced by mitochondrial dysfunction is a new signaling pathway that impairs cell proliferation [38].

The goal of the present work was to study the effect of AST on the functional state of rat heart mitochondria (RHM) under the conditions of mPTP opening and mitochondrial swelling by both direct addition of AST to mitochondria and AST administration. In addition, we wanted to check how AST changes the level of regulatory proteins of mPTP. We studied the involvement of AST in Akt/CREB signaling pathways in mitochondria under mPTP opening.

\section{Materials and Methods}

\subsection{Animals and Treatment}

Five 2-month-old male Wistar rats (240-250 g weight) were used in the experiments. For each separate experiment, one rat was used; thus, 5 independent replicates were done. Animals were individually housed in a temperature-controlled room $\left(22{ }^{\circ} \mathrm{C}\right)$ and kept on a standard diet with free access to water and food. All experiments were performed in accordance with the Regulations for Studies with Experimental Animals (Decree of the Russian Ministry of Health of 12 August 1997, No. 755). The protocol was approved by the Commission on Biological Safety and Ethics at the Institute of Theoretical and Experimental Biophysics, Russian Academy of Sciences (March 2019, protocol N18/2019).

For AST administration, we used 2 groups of rats ( 5 rats in each group). The first group of rats was the control group, and the second group was treated with AST. AST was administered orally using plastic feeding tubes, 15 ga $\times 78 \mathrm{~mm}$ (Instech, Plymouth Meeting, PA, USA). The second group of rats was treated with food supplemented with $150 \mathrm{mg} / \mathrm{kg}$ of $5 \%$ astaxanthin (Natural, China) orally every day for 2 weeks. A weighed quantity of AST was dissolved in olive oil, which was chosen as the vehicle because AST is soluble in olive oil. For purity of the experiment, the control group of rats received olive oil in the same volume as the experimental group. After 2 weeks, RHM were isolated from the hearts of rats in each group.

\subsection{Isolation of Rat Heart Mitochondria}

Mitochondria were isolated from the whole hearts by the standard technique [39]. Each isolated heart was chopped, cleared of blood vessels, and destroyed with a glass homogenizer in a 10-fold volume of a medium containing $75 \mathrm{mM}$ sucrose, $10 \mathrm{mM}$ Tris- $\mathrm{HCl}$ (pH 7.4), $225 \mathrm{mM}$ mannitol, $1 \mathrm{mM}$ EDTA, and $0.1 \%$ BSA at $4{ }^{\circ} \mathrm{C}$. The homogenate was centrifuged at $1000 \times g$ for $10 \mathrm{~min}$, and the pellet was removed. Mitochondria contained in the supernatant were sedimented at $6000 \times g$ for $10 \mathrm{~min}$ at $4{ }^{\circ} \mathrm{C}$. Then, the mitochondrial pellet was washed with the isolation medium without EDTA and BSA $(6000 \times g, 10 \mathrm{~min})$ and suspended in the same medium. The protein content in mitochondria was 
determined using the Bradford assay. Protein concentration in RHM suspension was 30-35 mg/mL. Isolated mitochondria were kept for $2 \mathrm{~h}$ at $4{ }^{\circ} \mathrm{C}$.

\subsection{Evaluation of Mitochondrial Functions}

In the experiments, mitochondria were preincubated with AST (Sigma, USA) for $10 \mathrm{~min}$, after which mitochondria with AST were added to the multifunctional chamber with the incubation medium and incubated until the addition of $\mathrm{Ca}^{2+}$ for 3-5 min. The $\mathrm{Ca}^{2+}$ flow and $\mathrm{Ca}^{2+}$ retention capacity (CRC) of RHM were determined with $\mathrm{TPP}^{+}$- and $\mathrm{Ca}^{2+}$-sensitive electrodes (Nico, Russia), and the oxygen consumption rate was measured with a Clark-type $\mathrm{O}_{2}$ electrode in a $1 \mathrm{~mL}$ measuring chamber [40]. Mitochondria ( $1 \mathrm{mg}$ protein $/ \mathrm{mL}$ ) were incubated in a medium containing $125 \mathrm{mM} \mathrm{KCl}, 10 \mathrm{mM}$ Tris (pH 7.4), and $2 \mathrm{mM} \mathrm{K}_{2} \mathrm{HPO}_{4}$ at $25^{\circ} \mathrm{C}$. In the experiments, glutamate $(5 \mathrm{mM})$ and malate $(5 \mathrm{mM})$ were used as respiratory substrates. The respiratory control index (RCI) was measured in a closed chamber after the addition of $150 \mu \mathrm{M}$ ADP to RHM. mPTP opening in RHM was induced by a threshold $\left[\mathrm{Ca}^{2+}\right]$ concentration (first addition of $\mathrm{Ca}^{2+}$ contained $50 \mathrm{nM}$ per $\mathrm{mg}$ of protein; the next additions of $\mathrm{Ca}^{2+}$ were $100 \mathrm{nM}$ per mg of protein). A threshold $\left[\mathrm{Ca}^{2+}\right]$ concentration is the concentration of $\mathrm{Ca}^{2+}$ added to a mitochondrial suspension at which $\mathrm{Ca}^{2+}$ ions (when accumulating in mitochondria) induce mPTP opening. Parameters of $\mathrm{Ca}^{2+}$ transport, such as rates of influx ( $\mathrm{V}^{\mathrm{Ca} 2+}{ }_{\mathrm{in}}, \mathrm{nmol} \mathrm{min}{ }^{-1} \mathrm{mg}^{-1}$ of protein), efflux ( $\mathrm{V}^{\mathrm{Ca} 2+}{ }_{\mathrm{out}}, \mathrm{nmol} \mathrm{min}^{-1} \mathrm{mg}^{-1}$ protein), and lag-phase (time between influx and efflux, $\Delta$ Tlag, s) were measured. $\mathrm{V}^{\mathrm{Ca} 2+}{ }_{\text {in }}$ is the rate of $\mathrm{Ca}^{2+}$ influx during the last $\mathrm{Ca}^{2+}$ addition. $\mathrm{V}^{\mathrm{Ca} 2+}{ }_{\text {out }}$ is the rate of $\mathrm{Ca}^{2+}$ efflux after $\mathrm{Ca}^{2+}$ release. Lag-phase shows the time between influx and efflux during the last $\mathrm{Ca}^{2+}$ addition. The $\mathrm{Ca}^{2+}$-induced dissipation of membrane potential was calculated as $\mathrm{TPP}^{+}$efflux rate ( $\mathrm{V}^{\mathrm{TPP}}{ }_{\text {out }}, \mathrm{nmol} \mathrm{min}^{-1} \mathrm{mg}^{-1}$ of protein).

RHM swelling was measured as a change in light scattering in a mitochondrial suspension at $540 \mathrm{~nm}$ (A540) using a Tecan I-Control Infinite 200 spectrophotometer at $25^{\circ} \mathrm{C}$. The standard incubation medium for the swelling assay contained $125 \mathrm{mM} \mathrm{KCl}, 10 \mathrm{mM}$ Tris, $2 \mathrm{mM} \mathrm{KH}_{2} \mathrm{PO}_{4}, 5 \mathrm{mM}$ glutamate, and $5 \mathrm{mM}$ malate. The concentration of mitochondrial protein in a well was $0.5 \mathrm{mg}$ protein $/ \mathrm{mL}$. Swelling was initiated by the addition of $260 \mathrm{nmol} \mathrm{of} \mathrm{Ca}^{2+}$ per $\mathrm{mg}$ of protein. The swelling process was characterized by the time needed to reach the half-maximal light scattering signal $\left(\mathrm{T}_{1 / 2}\right)$.

\subsection{The Sample Preparation, Electrophoresis, and Immunoblotting of Mitochondrial Proteins}

To prepare samples for the determination of regulator protein levels, aliquots of isolated intact RHM from each group were placed in an Eppendorf tube and solubilized in Laemmli buffer (Bio-Rad, USA). Then, the samples were heated to $95^{\circ} \mathrm{C}$ for $3 \mathrm{~min}$. To determine pAKT and pCREB levels, $50 \mu \mathrm{L}$ aliquots were taken from the chamber and centrifuged at $15,000 \times \mathrm{g}$ for $3 \mathrm{~min}$. Pellets were taken and solubilized in Laemmli buffer. The samples were heated to $95^{\circ} \mathrm{C}$ for $3 \mathrm{~min}$.

Samples containing $20 \mu \mathrm{g}$ of mitochondrial protein were applied to each line and subjected to electrophoresis followed by western blot analysis. Precision Plus Pre-stained Standards from Bio-Rad Laboratories (Hercules, CA, USA) were used as markers.

Polyclonal anti-TSPO antibody (1:1000), monoclonal anti-cyclophilin D antibody (1:1000), and monoclonal anti-ATPG1/G2/G3 antibody-subunit $c$ (1:1000) were from Abcam. VDAC antibody (1:1000) was purchased from Calbiochem; polyclonal rabbit phospho-Akt (Ser473) and Akt antibodies (dilution 1:250) were from Cell Signaling; phospho-CREB (Ser133) and CREB (86B10) (dilution: 1:500) were from Cell Signaling. The COX IV antibody (1:1000 dilution; Abcam, USA) was used as the loading control. Immunoreactivity was detected using the appropriate secondary antibody conjugated to horseradish peroxidase (Jackson Immuno Research, West Grove, PA, USA). The blot was detected with ECL (Bio-Rad, Hercules, California, USA) using ChemiDoc Touch Imaging System (Bio-Rad, USA). Protein bands were quantified by densitometry (Image Lab program). 


\subsection{Statistical Analysis}

For statistical analysis, relative levels of protein density were expressed as means \pm SDs from at least 5 independent experiments. The statistical significance of the differences between pairs of mean values was evaluated using Student's $t$-tests. The difference was considered significant at $p<0.05$.

\section{Results}

\subsection{The Effect of AST on Respiratory Activity in Rat Heart Mitochondria}

First, we measured the respiratory activity of the RHM (Figure 1). The experiments were carried out as described in Materials and Methods. Figure 1a shows the curves of mitochondrial respiration in the absence or presence of two different concentrations of AST. The evaluation of oxygen consumption rates in different states is represented in Figure $1 \mathrm{~b}$. As seen from the figure, no changes occurred in the rate of states 3 and 4 when $0.5 \mu \mathrm{M}$ of AST was added to RHM in comparison with control (without AST). The addition of $5 \mu \mathrm{M}$ AST led to an increased respiration rate in state 3 by approximately $13 \%$ in comparison with control. In the presence of $5 \mu \mathrm{M}$ AST, the respiration rate in state 4 decreased by approximately $20 \%$ relative to control. The respiratory control index $(\mathrm{RCI})$ indicates the effectiveness of the mitochondria in promoting oxidative phosphorylation and coupling between oxygen consumption and ATP production. The results (Figure 1c) indicate that RHM incubated in standard medium with malate and glutamate in control conditions described in Material and Methods, exhibited an RCI of 2.7. The RCI of mitochondria in the presence of AST $(0.5 \mu \mathrm{M})$ did not differ from control. However, treatment of mitochondria with $5 \mu \mathrm{M}$ AST caused the RCI to increase to 3.9. Thus, $5 \mu \mathrm{M}$ AST increased the RCI of RHM by approximately $40 \%$ compared to control. The efficiency of oxidative phosphorylation in mitochondria is defined as the ratio of ATP to absorbed oxygen. We measured this parameter in the presence of both concentrations of AST. The phosphate/oxygen (P/O) ratio of RHM in the presence of $0.5 \mu \mathrm{M}$ AST (2) did not differ from the control value (2.1), whereas $5 \mu \mathrm{M}$ AST increased the $\mathrm{P} / \mathrm{O}$ ratio (2.73) by approximately $30 \%$.
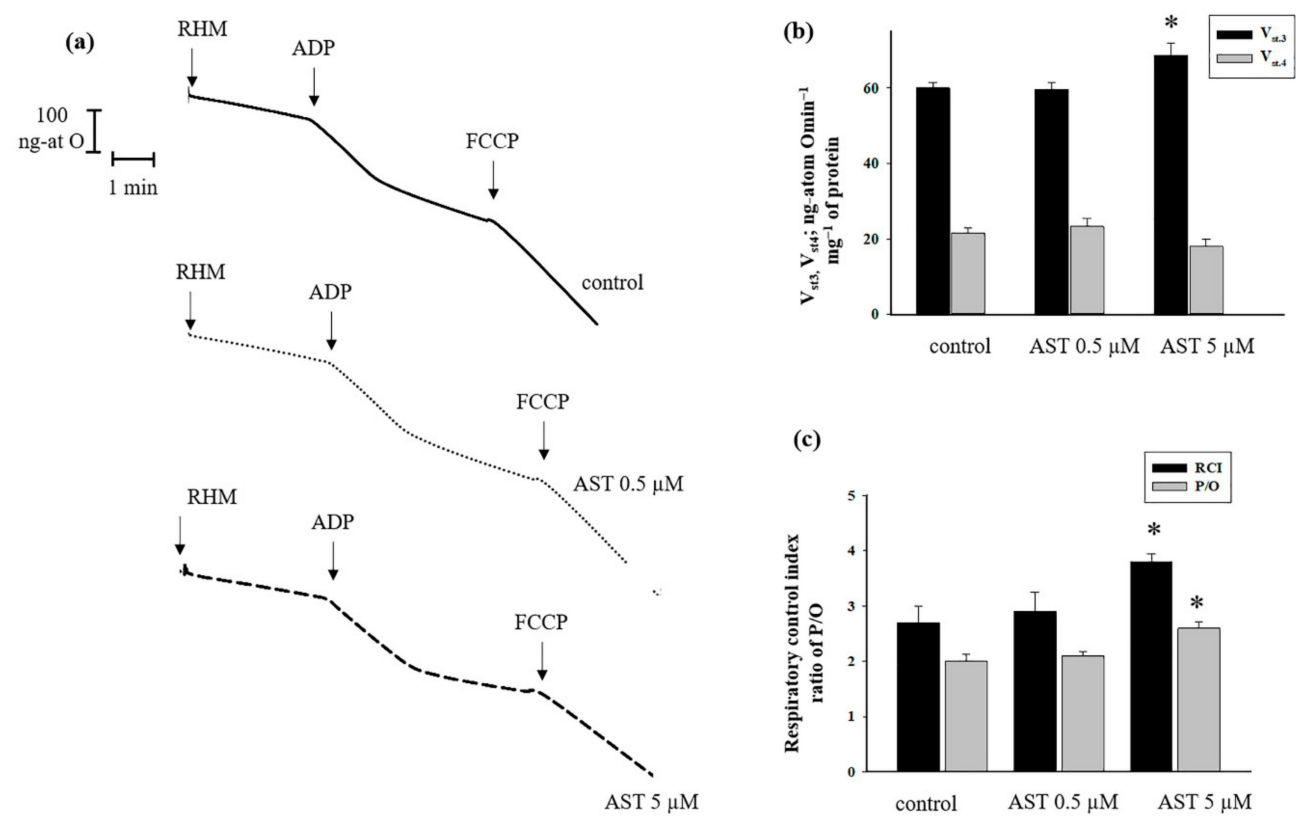

Figure 1. The Effect of astaxanthin (AST) on respiratory activity in rat heart mitochondria (RHM). RHM were incubated in standard medium as described in Materials and Methods. Arrows show the times at which FCCP (Carbonyl cyanide 4-(trifluoromethoxy) phenylhydrazone) and ADP (adenosine 5 '-diphosphate) were added. (a) Curves of respiratory activity; (b) quantitative analysis of RHM respiration rate in states 3 and 4 in the absence/presence of AST $(0.5$ and $5 \mu \mathrm{M})$; (c) values of respiratory control index (RCI) and phosphate/oxygen $(\mathrm{P} / \mathrm{O})$ ratio in the presence/absence of AST. Data are presented as means \pm SDs of five independent experiments. ${ }^{*} p<0.05$ compared with control (without AST). 


\subsection{The Effects of AST on $\mathrm{Ca}^{2+}$ Transport and $\mathrm{Ca}^{2+}$-Induced PTP Opening in Rat Heart Mitochondria}

Because mitochondrial dysfunction induced by oxidative stress can affect morphological and functional changes in mitochondria [41], the effects of induced mPTP opening in RHM by AST ( 0.5 and $5 \mu \mathrm{M})$ on $\mathrm{Ca}^{2+}$ transport, membrane potential $(\Delta \psi \mathrm{m})$, and calcium retention capacity (CRC) were examined. In Figure $2 \mathrm{a}-\mathrm{c}$, the curves of changes in $\mathrm{Ca}^{2+}$ flow in the control and in the presence of AST are shown.

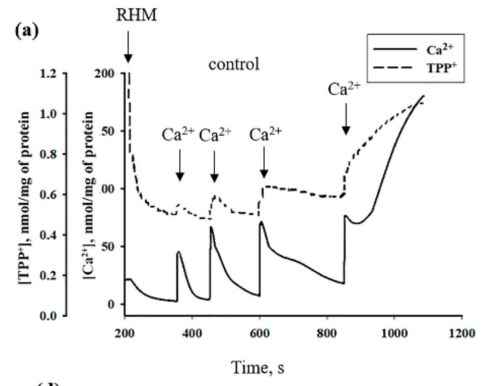

(d)

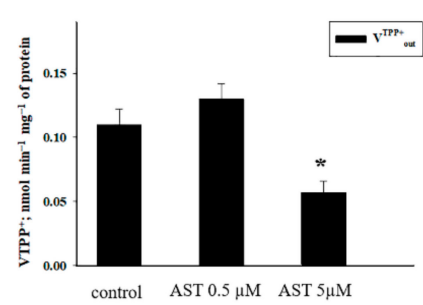

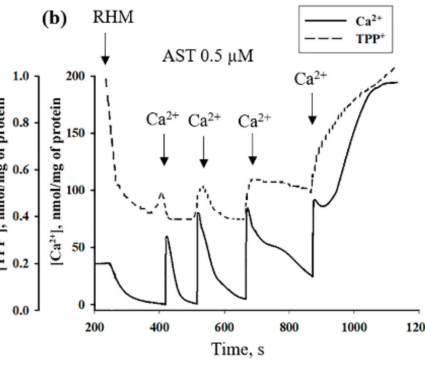

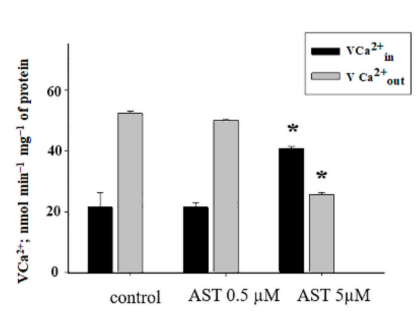

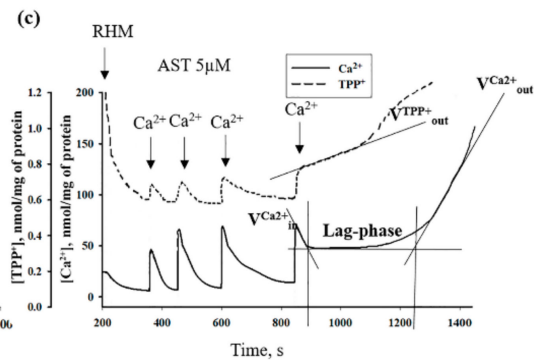

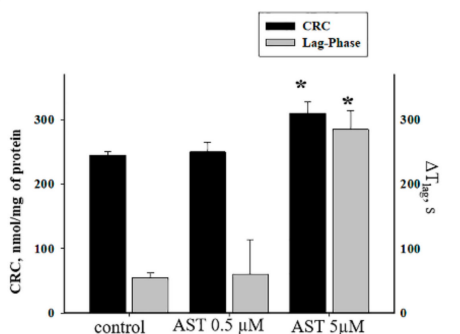

Figure 2. The effects of AST on $\mathrm{Ca}^{2+}$ transport, membrane potential, and CRC in RHM. Before being added to chamber, RHM were incubated with AST for $10 \mathrm{~min}$. Before the addition of $\mathrm{Ca}^{2+}$, mitochondria were incubated with AST for 3 min in chamber. (a) $\mathrm{Ca}^{2+}$ transport and membrane potential changes in RHM in control; (b) $\mathrm{Ca}^{2+}$ transport and membrane potential changes in RHM in the presence of $0.5 \mu \mathrm{M}$ AST; (c) $\mathrm{Ca}^{2+}$ transport and change of membrane potential in RHM in the presence of $0.5 \mu \mathrm{M}$ AST; (d) quantitative analysis of $\mathrm{V}^{\mathrm{TPP}}{ }_{\text {out; }}$ (e) quantitative analysis of $\mathrm{V}^{\mathrm{Ca} 2+}{ }_{\text {in }}$ and $\mathrm{V}^{\mathrm{Ca} 2+}{ }_{\text {out }}$ in RHM; (f) quantitative analysis of CRC and lag-phase. Data are presented as means \pm SDs of five independent experiments. ${ }^{*} p<0.05$ compared with control (without AST).

The first addition of $\mathrm{Ca}^{2+}(50 \mathrm{nmol}$ per $\mathrm{mg}$ of protein) led in all cases to a stable accumulation of $\mathrm{Ca}^{2+}$ in mitochondria followed by membrane potential recovery. The next additions of $\mathrm{Ca}^{2+}$ consisted of $100 \mathrm{nmol}$ per $\mathrm{mg}$ of protein, and the fourth $100 \mathrm{nmol}$ addition in control conditions resulted in $\mathrm{Ca}^{2+}$ release and mPTP opening (Figure 1a). In the presence of $0.5 \mu \mathrm{M}$ AST (Figure $2 \mathrm{~b}$ ), changes in $\mathrm{Ca}^{2+}$ flow (rate of $\mathrm{Ca}^{2+}$ uptake and efflux) did not differ from those of control. The addition of $5 \mu \mathrm{M}$ AST (Figure 2c) led to the activation of mPTP after the fourth addition of $\mathrm{Ca}^{2+}$ but after a prolonged lag-phase. In the presence of $5 \mu \mathrm{M}$ AST, CRC was increased by $26 \%$ (Figure $2 \mathrm{f}$ ) and the rate of TPP ${ }^{+}$ efflux was delayed doubly relative to the control (Figure 2d). The rates of $\mathrm{Ca}^{2+}$ uptake and efflux in control RHM were $21.5 \mathrm{nmol} \mathrm{min}^{-1} \mathrm{mg}-1$ and $52.25 \mathrm{nmol} \mathrm{min}^{-1} \mathrm{mg}-1$, respectively. In $5 \mu \mathrm{M}$ AST-treated RHM, the rate of $\mathrm{Ca}^{2+}$ uptake was increased to $40 \mathrm{nmol} \mathrm{min}^{-1} \mathrm{mg}^{-1}$ and the maximal $\mathrm{Ca}^{2+}$ efflux rate was diminished to $35.6 \mathrm{nmol} \mathrm{min}{ }^{-1} \mathrm{mg}-1$. Thus, the $\mathrm{Ca}^{2+}$ influx/efflux ratio was approximately $0.4 \mathrm{in}$ control mitochondria and 1.56 in $5 \mu \mathrm{M}$ AST-treated RHM. In the presence of $5 \mu \mathrm{M}$ AST, $\mathrm{Ca}^{2+}$ efflux and $\Delta \psi \mathrm{m}$ dissipation occurred after a prolonged lag-phase, and a significant amount of previously accumulated $\mathrm{Ca}^{2+}$ was retained in the mitochondrial matrix, even when $\Delta \psi \mathrm{m}$ was largely dissipated (Figure 2c). Thus, $5 \mu \mathrm{M}$ AST slowed down mPTP opening.

mPTP is known to be $\mathrm{Ca}^{2+}$-dependent and cyclosporin A (CsA)-sensitive [42,43]. In the presence of CsA, an additional fourth pulse of $\mathrm{Ca}^{2+}$ was tolerated without any efflux of mitochondrial $\mathrm{Ca}^{2+}$ and without collapse of $\Delta \psi \mathrm{m}$ in all experimental conditions (data not shown). Thus, the effects observed were CsA-sensitive, indicating the involvement of $\mathrm{mPTP}$ in the process. 


\subsection{The Effect of AST on the Swelling of Rat Heart Mitochondria}

To verify the inhibitory effect of AST, we examined another parameter that characterizes MPTP opening, $\mathrm{Ca}^{2+}$-induced swelling of mitochondria. The addition of $\mathrm{Ca}^{2+}$ at a threshold concentration to mitochondrial suspension incubated in a standard medium caused a decrease in light scattering, indicating swelling, and mitochondrial membranes became permeable to low-molecular-weight substances. The amount of $\mathrm{Ca}^{2+}$ added to mitochondria incubated in the presence of AST was $260 \mathrm{nmol}$ per mg of protein and corresponded to the control value (Figure 3). The curves of RHM swelling under different experimental conditions are shown in Figure 3 a. Figure $3 \mathrm{~b}$ quantitatively illustrates the course of the swelling process, characterized by the average half-maximal light scattering signal $\left(\mathrm{T}_{1 / 2}\right)$. It is visible in the figure that after the addition of $5 \mu \mathrm{M}$ AST to the mitochondrial suspension, the rate of mitochondrial swelling decreased by approximately $36 \%$, whereas after the addition of $0.5 \mu \mathrm{M}$ AST, the swelling rate did not differ from the control (threshold $\left[\mathrm{Ca}^{2+}\right]$, curve 2). CsA, confirming the participation of permeability transition, prevented mitochondrial swelling (curves 5-7). Because $0.5 \mu \mathrm{M}$ AST did not significantly affect the functional state of RHM and its effect did not differ from control, further studies were performed using only $5 \mu \mathrm{M}$ AST.

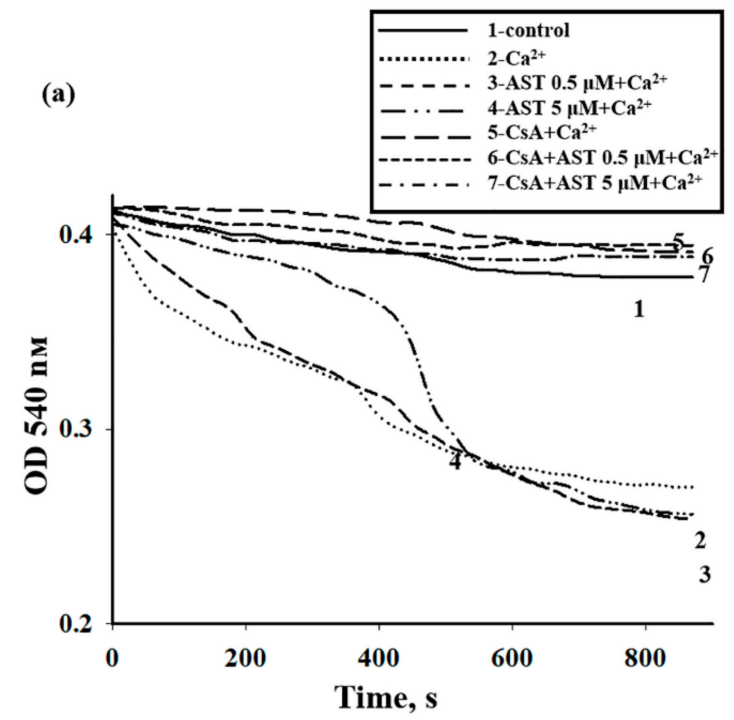

(b)

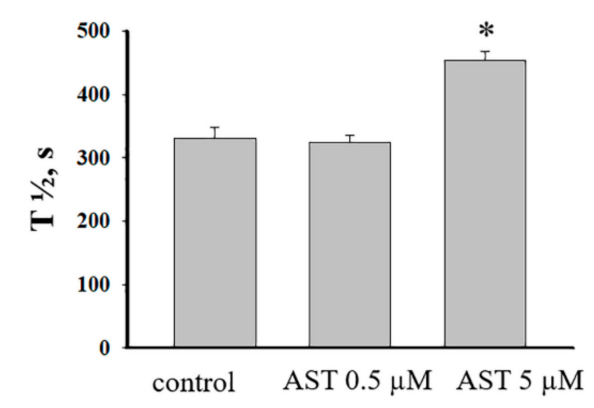

Figure 3. The effect of AST on $\mathrm{Ca}^{2+}$-induced swelling of RHM. (a) Curves of RHM swelling: in control conditions without $\mathrm{Ca}^{2+}$ (curve 1), in the presence of threshold $\left[\mathrm{Ca}^{2+}\right]$ alone (curve 2), and with $0.5 \mu \mathrm{M}$ AST (curve 3), $5 \mu \mathrm{M}$ AST (curve 4), cyclosporin A (CsA) (curve 5), CsA + $0.5 \mu \mathrm{M}$ AST (curve 6), and CsA $+5 \mu \mathrm{M}$ AST (curve 7). (b) Half-maximal mitochondrial swelling $\left(\mathrm{T}_{1 / 2}\right)$. Concentration of protein in a cuvette was $0.35 \mathrm{mg} / \mathrm{mL}$. Data are presented as means \pm SDs of five independent experiments. ${ }^{*} p<0.05$ compared with control (without AST).

\subsection{The Effect of AST Administration on Levels of Regulated Proteins of mPTP in Intact Rat} Heart Mitochondria

Taking into consideration that regulator proteins play an important role in $\mathrm{MPTP}$, in the present study, we examined how AST administration influences the levels of proteins such as CyP-D, TSPO, CNPase, subunit $c$, and VDAC in native RHM isolated from each group. The upper parts of Figure $4 \mathrm{a}-\mathrm{d}$ show western blots of the proteins in RHM isolated from each group of rats. Quantitative analysis of protein levels is shown in the lower parts of Figure 4a-d. Protein bands were quantified after normalization with respect to cytochrome c oxidase subunit IV (COX IV). As seen from Figure 4a, the TSPO level decreased by $20 \%$ in RHM isolated from the second group of rats compared to the first group of rats. After AST treatment, CyP-D and CNPase levels diminished by $15.5 \%$ and $32.6 \%$, respectively, in RHM related to control (Figure $4 \mathrm{~b}$ ). In RHM isolated from the second group, the VDAC 
level decreased 1.6 times (Figure 4c), whereas the level of subunit $c$ increased by 30\% (Figure 4d) in comparison with the first group of rats.

(a)
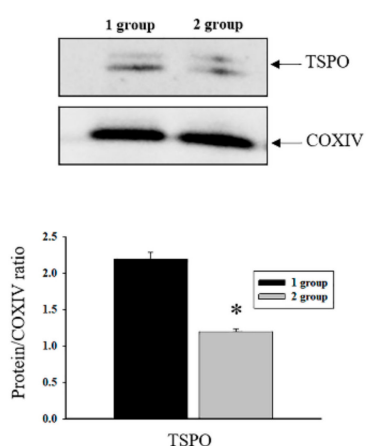

(b)
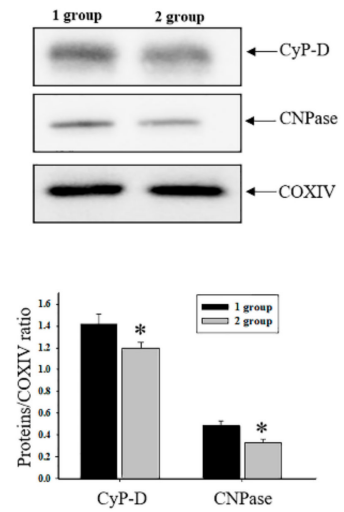

(c)
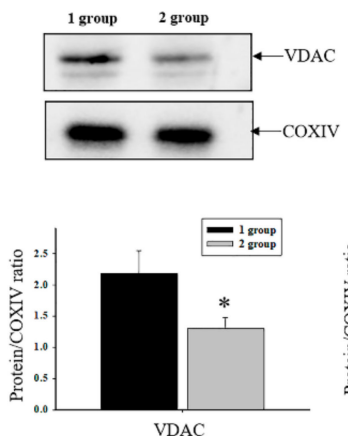
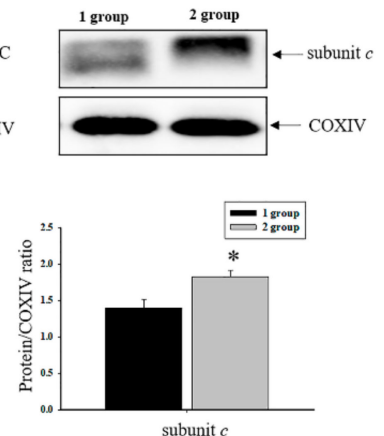

Figure 4. The effect of AST administration on mitochondrial protein content: cyclophilin D (CyP-D), translocator protein (TSPO), 2', 3'-cyclic nucleotide $3^{\prime}$-phosphodiesterase (CNPase), subunit $c$, and voltage-dependent anion channel (VDAC) in intact RHM from each group of rats. Antibody to cytochrome c oxidase subunit IV (COX IV) was used as loading control. (a-d) Upper parts: Western blots stained with corresponding antibodies; (lower parts): diagrams quantitatively reflecting changes in protein content in absolute units normalized to COX IV. Data are presented as means \pm SDs of five independent experiments. ${ }^{*} p<0.05$ - significant difference in protein level compared with control (RHM isolated from first group of rats).

3.5. The Effects of AST Administration on Respiratory Activity, CRC, and Mitochondrial Swelling in Rat Heart Mitochondria

To check the inhibitor effect of AST on mPTP functioning, we measured respiratory activity, CRC, and mitochondrial swelling in RHM isolated from two group of rats after AST administration (see Material and Methods). Therefore, the next step in our investigation was to measure the oxygen consumption rates in states 3 and 4, RCI, and P/O in RHM isolated from both groups of rats (Figure 5). Figure 5a shows representative curves of respiratory activity of RHM isolated from each group of rats. According to the experimental data, no substantial change was observed in the oxygen consumption rate in state 3 in RHM from the second group of rats compared to the first group. However, the oxygen consumption rate in state 4 in RHM from the second group of rats slowed down by $50 \%$ compared with the first group (Figure 5b). The RCI of RHM from the second group increased by $40 \%$ and was approximately 5.36, whereas the RCI of RHM from the first group was 4 (Figure $5 \mathrm{c}$ ). The $\mathrm{P} / \mathrm{O}$ ratio in RHM from the first group was 2, whereas in RHM from the second group it was 2.36, increasing by approximately $18 \%$. 
(a)

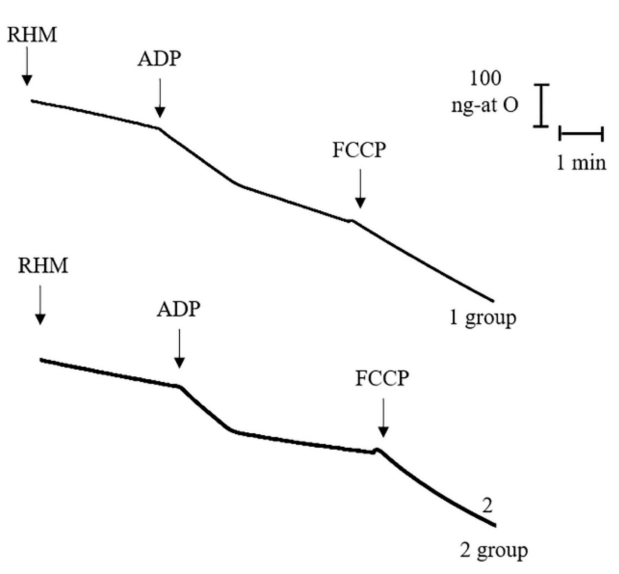

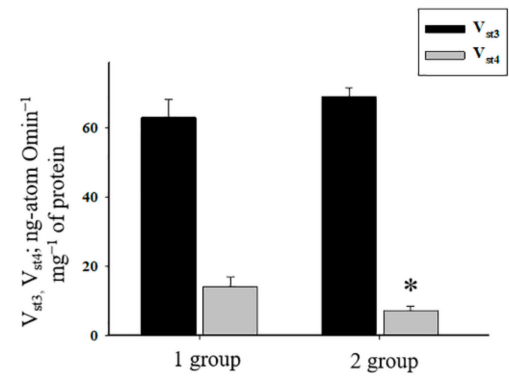

(c)

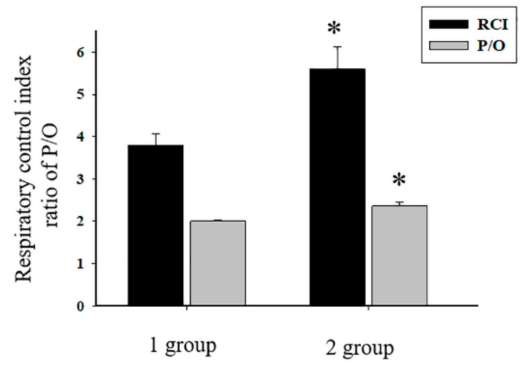

Figure 5. The effects of AST administration on respiratory activity in RHM isolated from each group. RHM were incubated in standard medium, as described in Materials and Methods. (a) Curves of respiratory activity; (b) quantitative analysis of RHM respiration rate in states 3 and 4; (c) $\mathrm{RCI}$ and $\mathrm{P} / \mathrm{O}$ values. Data are presented as means \pm SDs of five independent experiments. ${ }^{*} p<0.05$ compared with control (first group).

Then, we compared the swelling of RHM isolated from every group of rats. Figure 6a shows representative curves of $\mathrm{Ca}^{2+}$-activated swelling of RHM isolated from all groups of rats. Figure $6 \mathrm{~b}$ demonstrates the average half-maximum $\left(\mathrm{T}_{1 / 2}\right)$ of mitochondrial $\mathrm{Ca}^{2+}$-activated swelling. The half-maximum of the mitochondrial swelling of AST-treated rats increased by $30 \%$ (curve 4 versus 3). Thus, the rate of RHM swelling became slower compared to control. CsA inhibited mitochondrial swelling in RHM isolated from each group of rats.

(a)

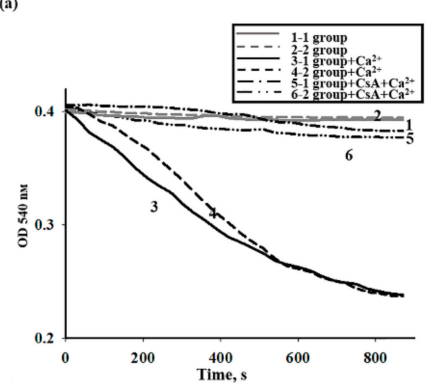

(b)

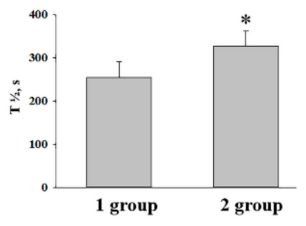

(c)

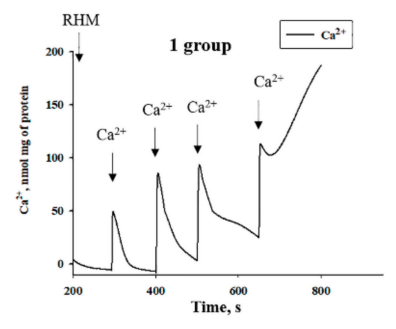

(d)

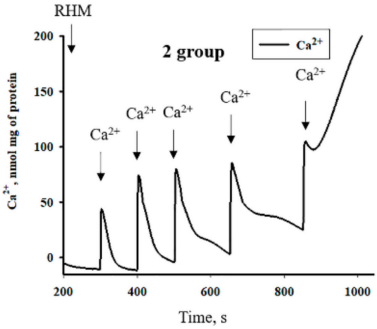

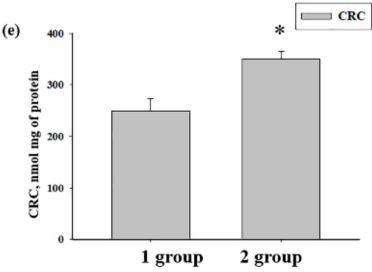

Figure 6. The effect of AST administration on mitochondrial swelling and CRC in RHM isolated from each group. (a) Curves of RHM swelling; (b) half-maximum of mitochondrial swelling $\left(\mathrm{T}_{1 / 2}\right)$; (c,d) $\mathrm{Ca}^{2+}$ transport in RHM isolated from each group; (e) quantitative analysis of CRC in RHM. 
The effect of AST administration on the MPTP function of RHM was examined. $\mathrm{Ca}^{2+}$ pulses were added to the mitochondria to reach a threshold $\mathrm{Ca}^{2+}$ concentration for $\mathrm{MPTP}$ opening as described in Figure 2. In RHM from each group, the first addition of $\mathrm{Ca}^{2+}$ led to an active accumulation of $\mathrm{Ca}^{2+}$ in mitochondria with subsequent restoration (Figure $6 c, d$ ). The release of accumulated $\mathrm{Ca}^{2+}$ (mPTP opening) occurred after the fourth and fifth $\mathrm{Ca}^{2+}$ additions in control and AST-treated groups, respectively. Figure 6e demonstrates quantitative changes in $\mathrm{Ca}^{2+}$ retention capacity in $\mathrm{Ca}^{2+}$-loaded RHM isolated from every experimental group of rats. We observed that AST administration increased $\mathrm{Ca}^{2+}$ retention capacity by $35 \%$ in RHM compared to control.

3.6. Changes in the Phosphorylation States of Activated CREB and Akt in Rat Heart Mitochondria after AST Administration during mPTP Opening

It is known that CREB is involved in signaling pathways, and that $\mathrm{Ca}^{2+}$ is capable of activating several kinase pathways in order to phosphorylate CREB at Ser133. CaMKI, II, and IV; p70S6K; rsk2; MSK; PKCs; Ras/Raf/MAPK; Akt; and MAPKAP-K2 are capable of phosphorylating CREB, facilitating interaction with the CREB-binding protein (CBP/p300) [44]. In addition, Akt (known as protein kinase B) directly affects mitochondria, protecting them from oxidants or MPTP opening [28]. Therefore, we examined how the levels of phosphorylated Akt and CREB changed in the presence of AST when mPTPs were open (Figure 7). The upper parts of Figure 7a,b show western blots stained with antibodies to pAkt, Akt, pCREB, and CREB. COX IV was used as a loading control. A quantitative analysis of pAkt/Akt and pCREB/CREB ratios is presented in the lower parts of Figure $7 \mathrm{a}, \mathrm{b}$. It is visible from the figure that the pAkt/Akt ratio decreased by $\sim 46 \%$ upon the induction of $\mathrm{mPTP}$ opening, whereas the $\mathrm{pCREB} / \mathrm{CREB}$ ratio decreased by $\sim 36 \%$ compared with control (column 2 versus 1). After AST treatment, the pAkt/Akt and pCREB/CREB ratios decreased by $\sim 25 \%$ and $\sim 20 \%$ respectively, compared to control (column 3 versus 1 ). After the addition of the threshold $\left[\mathrm{Ca}^{2+}\right]$ to RHM from AST-treated rats, the pAkt/Akt ratio diminished by $50 \%$, while the pCREB/CREB ratio decreased by $\sim 27 \%$ (column 4 versus 2 ). It should be noted that when $\mathrm{mPTP}$ was opened, AST decreased the $\mathrm{pAkt} /$ Akt ratio by $~ 65 \%$ and the $\mathrm{pCREB} / \mathrm{CREB}$ ratio by $\sim 27 \%$ compared with the effect of AST alone (without $\mathrm{Ca}^{2+}$ ) (column 4 versus 3).

(a)
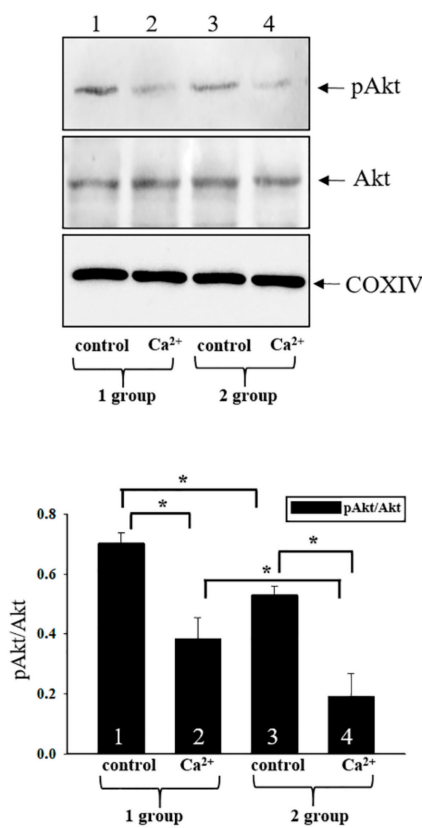

(b)
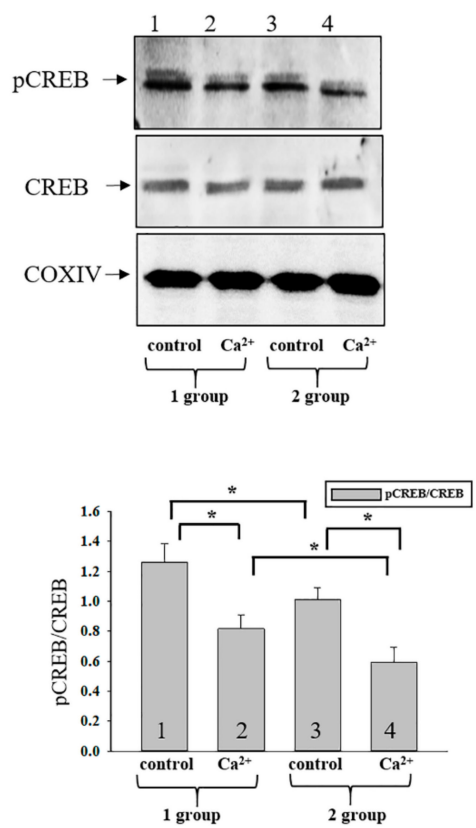

Figure 7. The effects of AST administration on pAkt and pCREB levels during mPTP opening. $(\mathbf{a}, \mathbf{b})$ Upper parts: Western blots stained with corresponding antibodies; lower parts: ratios of pCREB to total CREB, and pAkt to total Akt. COX IV was used as a loading control. Data are presented as means \pm SDs of five independent experiments. ${ }^{*} p<0.05$-significant difference in protein level compared with corresponding control. 


\section{Discussion}

Mitochondrial dysfunction induced by oxidative damage causes morphological and functional changes in mitochondria. In pathological states, structural changes occurring upon oxidative damage, such as swelling, fragmentation of mitochondria, and division of mitochondria, become more pronounced [41]. Oxidative stress in mitochondria can induce membrane permeabilization and the opening of nonspecific mPTP, which is considered the initial stage of apoptosis [6,45]. mPTP participates in the physiological calcium-release mechanisms that are required for proper metabolic regulation of the cell; this structure could be an important player in the regulation of heart development [46]. AST can diminish oxidative stress and maintain the integrity of mitochondria, as well as sustain mitochondrial function, protecting their redox balance [47]. In addition, it was shown that AST significantly decreases physiologically-arising oxidative stress and maintains mitochondria in a more reduced state even after stimulation with $\mathrm{H}_{2} \mathrm{O}_{2}$; it prevents a drop in membrane potential and increases oxygen consumption by mitochondria [48,49]. Park and coauthors showed that AST treatment increased the mitochondrial content, ATP production, and activity of respiratory chain complexes [50]. In our experiments, we observed that in the presence of both AST added to RHM and AST administration, the RCI and P/O ratio increased (Figures 1 and 5).

Recently, we showed that the addition of melatonin at concentrations of $10 \mathrm{nM}$ and $100 \mathrm{nM}$ to isolated rat-brain mitochondria triggered mPTP opening [51], while chronic administration of melatonin slowed down mPTP opening [52]. Here, we demonstrated that $\mathrm{Ca}^{2+}$-induced mPTP opening in isolated RHM was delayed by $5 \mu \mathrm{M}$ AST. The AST was able to suppress $\mathrm{Ca}^{2+}$-induced $\mathrm{Ca}^{2+} \mathrm{efflux}^{2}$ and membrane potential dissipation and increase CRC by $26 \%$. Mitochondrial swelling decreased by 36\% (Figures 2 and 3). Moreover, AST administration increased the CRC of RHM by 35\%, while the rate of mitochondrial swelling decreased by $30 \%$. AST prevented mitochondrial swelling and detained $\mathrm{Ca}^{2+}$ release from RHM both with the direct addition of AST and after AST administration (Figure 6). This result reveals the involvement of AST in MPTP functioning and supports the data in the literature showing an inhibitory effect of AST on oxidative stress-induced mitochondrial dysfunction in living cells [53].

TSPO is localized in the outer mitochondrial membrane at contact sites between the outer and inner membranes [54]. The role of TSPO in the heart has not been completely understood; however, it is known that the protein is implicated in the pathophysiology of cardiac diseases and its ligands improve heart function, which permits consideration of TSPO as a potential target for therapy of cardiovascular diseases [55]. The level of TSPO in the heart varies under different stress conditions; under chronic stress, the level decreases, whereas under acute stress, it increases [55]. Our study showed that the TSPO level in isolated RHM decreased, probably due to the inhibitory effect of AST treatment. (Figure 4a). TSPO can form a multimeric complex with VDAC (which is retained in a purified VDAC preparation [56]). Genetic studies have suggested that the composition of mPTP does not require VDAC [57]. However, VDAC can regulate the rate of $\mathrm{Ca}^{2+}$ entry into to the intermembrane space [42], thereby participating in the regulation of $\mathrm{mPTP}$. The decline of VDAC content in RHM isolated from AST-treated rats suggests a decreased rate of $\mathrm{Ca}^{2+}$ influx, and therefore slower mPTP opening.

CyP-D is a mitochondrial matrix protein considered a structural component and regulator of $\mathrm{mPTP}$, and is a prominent mediator of $\mathrm{mPTP}$. $\mathrm{mPTP}$, as regulated by CyP-D, appears to be a physiological $\mathrm{Ca}^{2+}$ release mechanism that is required for proper metabolic regulation within the mitochondria [58]. The loss of CyP-D does not prevent mPTP opening, but increases the $\mathrm{Ca}^{2+}$ load required before opening occurs [59]. A decline of CyP-D content in RHM isolated from AST-treated rats (Figure 4b) could lead to an increased $\mathrm{Ca}^{2+}$ load and slower mPTP opening (Figure 6). CyP-D directly binds the lateral stalk of ATP synthase and alters its activity [60]. CyP-D may control the assembly of the electron transport chain, making it a central node for the control of mitochondrial function [61]. Moreover, CyP-D interaction decreases ATP synthesis and hydrolysis rates to modulate both energy production and necrotic cell death [62]. Subunit $c$ of the $F_{0}$ sector of $F_{0} F_{1}$-ATPase is speculated to be a principal component of the $\mathrm{MPTP}$ complex. Subunit $c$ plays a critical role in the formation of the 
$\mathrm{Ca}^{2+}$-induced mPTP channel $[13,63,64]$. In the presence of threshold $\left[\mathrm{Ca}^{2+}\right]$, dephosphorylated subunit $c$ has the ability to promote mPTP opening and induce mitochondrial swelling, and lower $\mathrm{Ca}^{2+}$ uptake capacity and $\Delta \psi \mathrm{m}$. The level of subunit $c$ decreased in mitochondria [13]. Here, in RHM isolated from AST-treated rats, the subunit $c$ content increased, which contributed to increased $\mathrm{Ca}^{2+}$ capacity and a slowing of mitochondrial swelling.

Recently, we showed that CNPase was co-precipitated with CyP-D, ANT, and VDAC as well as a-tubulin in $\mathrm{Ca}^{2+}$-loaded and control mitochondria, indicating a possible physical association between these proteins in mitochondria [8]. In particular, CNPase, residing on the outer membrane, could tightly interact with VDAC, determining the permeability of the outer mitochondrial membrane. VDAC channels can be in an open or closed state. In the VDAC closed state, its channels are more permeable for $\mathrm{Ca}^{2+}$ [65], which might lead to acceleration of mPTP opening. Both VDAC and CNPase bind to $\alpha$-tubulin. Binding of $\alpha$-tubulin to VDAC promotes its closure [66]. Thus, CNPase might regulate VDAC conductance directly or through $\alpha$-tubulin binding, followed by modulation of outer membrane permeability in mitochondria. Threshold $\left[\mathrm{Ca}^{2+}\right]$ loading promotes rearrangement of mPTP regulators/modulators, which may cause MPTP opening. The decreased level of VDAC in RHM from AST-treated rats may be a reason for changes in the sensitivity to $\mathrm{Ca}^{2+}$ upon the AST-evoked inhibition of mPTP in RHM.

Akt is a key participant in the regulation of cellular signals, which are important for cell death and survival [67]. Akt directly affects mitochondria, protecting them from oxidants or mPTP opening $[28,68]$. VDAC is considered to be a direct substrate of pAkt [69]. Akt is present in mitochondria, and the level of Akt in mitochondria is dynamically regulated by cellular signaling activities. In mitochondria, Akt phosphorylates the $\beta$ subunit of ATP synthase, GSK-3 $\beta$, and the mitochondrial form of hexokinase II, which promotes the association of hexokinase II with VDAC [70]. The result of this association is decreased conductivity of VDAC. Akt has been shown to phosphorylate VDAC in isolated heart mitochondria [71]. The results of our observations show that inactivation of pAkt could lead to a reduction in the VDAC level and inhibition of MPTP.

Wang and coauthors showed that AST was able to activate the cAMP/PKA/CREB signaling pathway in brain tissues [72]. Recently, we showed that CNPase was phosphorylated by PKA in rat brain mitochondria [73]; thus, CNPase could be a target of the AST effect in RHM. Moreover, CREB is a downstream substrate of Akt. Phosphorylation of CREB by Akt at Ser133 leads to activation of its transcription and inhibition of apoptosis [32]. Activated CREB inhibits mitochondrial activity, impairing the mitochondrial state [37]. Our results show that AST decreased CREB signaling and improved the mitochondrial state. Because MPTP is considered to be the initial stage of apoptosis [45] and the addition of AST inhibited the induction of MPTP opening, activation of Akt and CREB being inhibited in this case, it may be suggested that AST is capable of improving RHM functions, which constitute an important factor in the normal functioning of the heart. These data provide the impetus for further studies of the therapeutic potential of AST in the treatment and prevention of heart diseases.

\section{Conclusions}

To summarize, the results of the study suggest that AST is capable of improving the functional state of RHM, increasing RCI and P/O ratios both with direct addition of AST to RHM and AST administration. AST, a dietary carotenoid, is considered a mitochondrion-permeable antioxidant [49] that can penetrate the mitochondria, and is effective in preventing $\mathrm{MPTP}$ opening. TSPO and its ligands activate oxidative stress and apoptosis [74], which can lead to MPTP opening. TSPO interacts with VDAC and is capable of forming a firm complex with it [56]. CNPase, residing on the outer membrane, can tightly interact with VDAC, determining the permeability of the outer mitochondrial membrane [8]. AST treatment reduced the levels of TSPO, VDAC, and CNPase in native RHM, thereby detaining mPTP opening. A decreased content of CyP-D in RHM isolated from AST treated rats can lead to an increased content of subunit $c$ and $\mathrm{Ca}^{2+}$ capacity, thereby slowing down mPTP opening. AST treatment could delay $\mathrm{Ca}^{2+}$-induced $\mathrm{Ca}^{2+}$ release. AST administration blocked activated Akt in 
RHM. Phosphorylation of CREB (as a downstream Akt substrate) by Akt resulted in its transcriptional activation and inhibition of apoptosis [32,75]; we observed that the level of activated CREB was attenuated by AST administration. Since AST improves the resistance of RHM to $\mathrm{Ca}^{2+}$-dependent stress, it can be assumed that after further studies, this antioxidant can be considered an effective tool for improving the functioning of the heart muscle in general under normal and clinical conditions. Determining the effect of AST on cardiomyocyte cells and investigating the functional state of RHM after chronic administration of AST in heart failure are the aims of our further studies.

Author Contributions: Conceptualization, O.K. and Y.B.; methodology, L.S.; software, R.K.; validation, A.K., I.O., and R.K.; formal analysis, Y.B.; investigation, R.K.; resources, O.K.; data curation, A.K.; writing-original draft preparation, O.K.; writing-review and editing, I.O.; visualization, Y.B.; supervision, O.K.; funding acquisition, O.K.

Funding: This research were funded by RFBR, grant numbers 17-04-00747 and 19-04-00327.

Acknowledgments: The work was carried out using the equipment of the Center for the Collective Use of Research Equipment of the Institute of Theoretical and Experimental Biophysics of the Russian Academy of Sciences.

Conflicts of Interest: The authors declare no conflict of interest.

\section{References}

1. Rezin, G.T.; Amboni, G.; Zugno, A.I.; Quevedo, J.; Streck, E.L. Mitochondrial dysfunction and psychiatric disorders. Neurochem Res. 2009, 34, 1021-1029. [CrossRef] [PubMed]

2. Miquel, J.; Economos, A.C.; Fleming, J.; Johnson, J.E., Jr. Mitochondrial role in cell aging. Exp. Gerontol. 1980, 15, 575-591. [CrossRef]

3. Lopez, A.D.; Murray, C.C. The global burden of disease, 1990-2020. Nat. Med. 1998, 4, 1241-1243. [CrossRef] [PubMed]

4. Griffiths, E.J. Mitochondria and heart disease. Adv. Exp. Med. Biol. 2012, 942, 249-267. [PubMed]

5. Szalai, G.; Krishnamurthy, R.; Hajnoczky, G. Apoptosis driven by IP(3)-linked mitochondrial calcium signals. EMBO J. 1999, 18, 6349-6361. [CrossRef]

6. Halestrap, A.P. What is the mitochondrial permeability transition pore? J. Mol. Cell. Cardiol. 2009, 46, 821-831. [CrossRef]

7. Azarashvili, T.; Krestinina, O.; Galvita, A.; Grachev, D.; Baburina, Y.; Stricker, R.; Evtodienko, Y.; Reiser, G. $\mathrm{Ca}^{2+}$-dependent permeability transition regulation in rat brain mitochondria by $2^{\prime}, 3^{\prime}$-cyclic nucleotides and 2' $3^{\prime}$-cyclic nucleotide 3'-phosphodiesterase. Am. J. Physiol. Cell Physiol. 2009, 296, C1428-C1439. [CrossRef]

8. Baburina, Y.; Azarashvili, T.; Grachev, D.; Krestinina, O.; Galvita, A.; Stricker, R.; Reiser, G. Mitochondrial 2', $3^{\prime}$-cyclic nucleotide $3^{\prime}$-phosphodiesterase (CNP) interacts with mPTP modulators and functional complexes (I-V) coupled with release of apoptotic factors. Neurochem. Int. 2015, 90, 46-55. [CrossRef]

9. Odinokova, I.V.; Baburina, Y.L.; Kruglov, A.G.; Santalova, I.M.; Azarashvili, T.S.; Krestinina, O.V. Operation of the Permeability Transition Pore in Rat Heart Mitochondria in Aging. Biochem. Mosc. Suppl. Ser. A Membr. Cell Biol. 2018, 12, 137-145. [CrossRef]

10. Celis, H. 1-Butanol extracted proteolipid. Proton conducting properties. Biochem. Biophys. Res. Commun. 1980, 92, 26-31. [CrossRef]

11. Wittig, I.; Schagger, H. Structural organization of mitochondrial ATP synthase. Biochim. Biophys. Acta Bioenerg. 2008, 1777, 592-598. [CrossRef] [PubMed]

12. Dyer, M.R.; Walker, J.E. Sequences of members of the human gene family for the $\mathrm{c}$ subunit of mitochondrial ATP synthase. Biochem. J. 1993, 293, 51-64. [CrossRef] [PubMed]

13. Azarashvili, T.; Odinokova, I.; Bakunts, A.; Ternovsky, V.; Krestinina, O.; Tyynela, J.; Saris, N.E. Potential role of subunit $\mathrm{c}$ of F0F1-ATPase and subunit $\mathrm{c}$ of storage body in the mitochondrial permeability transition. Effect of the phosphorylation status of subunit c on pore opening. Cell Calcium 2014, 55, 69-77. [CrossRef] [PubMed]

14. Walters, A.M.; Porter, G.A., Jr.; Brookes, P.S. Mitochondria as a drug target in ischemic heart disease and cardiomyopathy. Circ. Res. 2012, 111, 1222-1236. [CrossRef] [PubMed]

15. Ingwall, J.S. On the control of metabolic remodeling in mitochondria of the failing heart. Circ. Heart Fail. 2009, 2, 275-277. [CrossRef] 
16. Keith, M.; Geranmayegan, A.; Sole, M.J.; Kurian, R.; Robinson, A.; Omran, A.S.; Jeejeebhoy, K.N. Increased oxidative stress in patients with congestive heart failure. J. Am. Coll. Cardiol. 1998, 31, 1352-1356. [CrossRef]

17. Luo, M.; Anderson, M.E. Mechanisms of altered $\mathrm{Ca}(2)(+)$ handling in heart failure. Circ. Res. 2013, 113, 690-708. [CrossRef]

18. Kwong, J.Q.; Molkentin, J.D. Physiological and pathological roles of the mitochondrial permeability transition pore in the heart. Cell Metab. 2015, 21, 206-214. [CrossRef]

19. Jennings, R.B.; Reimer, K.A.; Steenbergen, C. Effect of inhibition of the mitochondrial ATPase on net myocardial ATP in total ischemia. J. Mol. Cell. Cardiol. 1991, 23, 1383-1395. [CrossRef]

20. Murphy, E.; Steenbergen, C. Mechanisms underlying acute protection from cardiac ischemia-reperfusion injury. Physiol. Rev. 2008, 88, 581-609. [CrossRef]

21. Ong, S.B.; Dongworth, R.K.; Cabrera-Fuentes, H.A.; Hausenloy, D.J. Role of the MPTP in conditioning the heart-translatability and mechanism. Br. J. Pharmacol. 2015, 172, 2074-2084. [CrossRef] [PubMed]

22. Yuan, J.P.; Peng, J.; Yin, K.; Wang, J.H. Potential health-promoting effects of astaxanthin: A high-value carotenoid mostly from microalgae. Mol. Nutr. Food Res. 2011, 55, 150-165. [CrossRef] [PubMed]

23. Ambati, R.R.; Phang, S.M.; Ravi, S.; Aswathanarayana, R.G. Astaxanthin: Sources, extraction, stability, biological activities and its commercial applications-A review. Mar. Drugs 2014, 12, 128-152. [CrossRef] [PubMed]

24. Higuera-Ciapara, I.; Felix-Valenzuela, L.; Goycoolea, F.M. Astaxanthin: A review of its chemistry and applications. Crit. Rev. Food Sci. Nutr. 2006, 46, 185-196. [CrossRef] [PubMed]

25. Pongkan, W.; Takatori, O.; Ni, Y.; Xu, L.; Nagata, N.; Chattipakorn, S.C.; Usui, S.; Kaneko, S.; Takamura, M.; Sugiura, M.; et al. beta-Cryptoxanthin exerts greater cardioprotective effects on cardiac ischemia-reperfusion injury than astaxanthin by attenuating mitochondrial dysfunction in mice. Mol. Nutr. Food Res. 2017, 61, 1601077. [CrossRef] [PubMed]

26. Fan, C.D.; Sun, J.Y.; Fu, X.T.; Hou, Y.J.; Li, Y.; Yang, M.F.; Fu, X.Y.; Sun, B.L. Astaxanthin Attenuates Homocysteine-Induced Cardiotoxicity in Vitro and in Vivo by Inhibiting Mitochondrial Dysfunction and Oxidative Damage. Front. Physiol. 2017, 8, 1041. [CrossRef]

27. Sasaki, K.; Sato, M.; Umezawa, Y. Fluorescent indicators for Akt/protein kinase B and dynamics of Akt activity visualized in living cells. J. Biol. Chem. 2003, 278, 30945-30951. [CrossRef]

28. Miyamoto, S.; Murphy, A.N.; Brown, J.H. Akt mediates mitochondrial protection in cardiomyocytes through phosphorylation of mitochondrial hexokinase-II. Cell Death Differ. 2008, 15, 521-529. [CrossRef]

29. Yang, J.Y.; Deng, W.; Chen, Y.; Fan, W.; Baldwin, K.M.; Jope, R.S.; Wallace, D.C.; Wang, P.H. Impaired translocation and activation of mitochondrial Akt1 mitigated mitochondrial oxidative phosphorylation Complex V activity in diabetic myocardium. J. Mol. Cell. Cardiol. 2013, 59, 167-175. [CrossRef]

30. Bijur, G.N.; Jope, R.S. Rapid accumulation of Akt in mitochondria following phosphatidylinositol 3-kinase activation. J. Neurochem. 2003, 87, 1427-1435. [CrossRef]

31. Mootha, V.K.; Bunkenborg, J.; Olsen, J.V.; Hjerrild, M.; Wisniewski, J.R.; Stahl, E.; Bolouri, M.S.; Ray, H.N.; Sihag, S.; Kamal, M.; et al. Integrated analysis of protein composition, tissue diversity, and gene regulation in mouse mitochondria. Cell 2003, 115, 629-640. [CrossRef]

32. Socodato, R.; Brito, R.; Portugal, C.C.; de Oliveira, N.A.; Calaza, K.C.; Paes-de-Carvalho, R. The nitric oxide-cGKII system relays death and survival signals during embryonic retinal development via AKT-induced CREB1 activation. Cell Death Differ. 2014, 21, 915-928. [CrossRef] [PubMed]

33. Scacco, S.; Vergari, R.; Scarpulla, R.C.; Technikova-Dobrova, Z.; Sardanelli, A.; Lambo, R.; Lorusso, V.; Papa, S. cAMP-dependent phosphorylation of the nuclear encoded $18-\mathrm{kDa}$ (IP) subunit of respiratory complex I and activation of the complex in serum-starved mouse fibroblast cultures. J. Biol. Chem. 2000, 275, 17578-17582. [CrossRef] [PubMed]

34. Gopalakrishnan, L.; Scarpulla, R.C. Differential regulation of respiratory chain subunits by a CREB-dependent signal transduction pathway. Role of cyclic AMP in cytochrome c and COXIV gene expression. J. Biol. Chem. 1994, 269, 105-113.

35. Kim, H.P.; Roe, J.H.; Chock, P.B.; Yim, M.B. Transcriptional activation of the human manganese superoxide dismutase gene mediated by tetradecanoylphorbol acetate. J. Biol. Chem. 1999, 274, 37455-37460. [CrossRef]

36. Brady, P.S.; Park, E.A.; Liu, J.S.; Hanson, R.W.; Brady, L.J. Isolation and characterization of the promoter for the gene coding for the $68 \mathrm{kDa}$ carnitine palmitoyltransferase from the rat. Biochem. J. 1992, 286, 779-783. [CrossRef] 
37. Vankoningsloo, S.; De Pauw, A.; Houbion, A.; Tejerina, S.; Demazy, C.; de Longueville, F.; Bertholet, V.; Renard, P.; Remacle, J.; Holvoet, P.; et al. CREB activation induced by mitochondrial dysfunction triggers triglyceride accumulation in 3T3-L1 preadipocytes. J. Cell Sci. 2006, 119, 1266-1282. [CrossRef]

38. Arnould, T.; Vankoningsloo, S.; Renard, P.; Houbion, A.; Ninane, N.; Demazy, C.; Remacle, J.; Raes, M. CREB activation induced by mitochondrial dysfunction is a new signaling pathway that impairs cell proliferation. EMBO J 2002, 21, 53-63. [CrossRef]

39. Odinokova, I.; Baburina, Y.; Kruglov, A.; Fadeeva, I.; Zvyagina, A.; Sotnikova, L.; Akatov, V.; Krestinina, O. Effect of Melatonin on Rat Heart Mitochondria in Acute Heart Failure in Aged Rats. Int. J. Mol. Sci. 2018, 19, 1555. [CrossRef]

40. Azarashvili, T.; Grachev, D.; Krestinina, O.; Evtodienko, Y.; Yurkov, I.; Papadopoulos, V.; Reiser, G. The peripheral-type benzodiazepine receptor is involved in control of $\mathrm{Ca}^{2+}$-induced permeability transition pore opening in rat brain mitochondria. Cell Calcium 2007, 42, 27-39. [CrossRef]

41. Kim, S.H.; Lim, J.W.; Kim, H. Astaxanthin Inhibits Mitochondrial Dysfunction and Interleukin-8 Expression in Helicobacter pylori-Infected Gastric Epithelial Cells. Nutrients 2018, 10, 1320. [CrossRef] [PubMed]

42. Hurst, S.; Hoek, J.; Sheu, S.S. Mitochondrial $\mathrm{Ca}(2+)$ and regulation of the permeability transition pore. J. Bioenerg. Biomembr. 2017, 49, 27-47. [CrossRef] [PubMed]

43. Broekemeier, K.M.; Dempsey, M.E.; Pfeiffer, D.R. Cyclosporin A is a potent inhibitor of the inner membrane permeability transition in liver mitochondria. J. Biol. Chem. 1989, 264, 7826-7830. [PubMed]

44. De Cesare, D.; Fimia, G.M.; Sassone-Corsi, P. Signaling routes to CREM and CREB: Plasticity in transcriptional activation. Trends Biochem. Sci. 1999, 24, 281-285. [CrossRef]

45. Zoratti, M.; Szabo, I.; De Marchi, U. Mitochondrial permeability transitions: How many doors to the house? Biochim. Biophys. Acta Bioenerg. 2005, 1706, 40-52. [CrossRef] [PubMed]

46. Perez, M.J.; Quintanilla, R.A. Development or disease: Duality of the mitochondrial permeability transition pore. Dev. Biol. 2017, 426, 1-7. [CrossRef] [PubMed]

47. Wolf, A.M.; Asoh, S.; Hiranuma, H.; Ohsawa, I.; Iio, K.; Satou, A.; Ishikura, M.; Ohta, S. Astaxanthin protects mitochondrial redox state and functional integrity against oxidative stress. J. Nutr. Biochem. 2010, 21, 381-389. [CrossRef]

48. Kuroki, T.; Ikeda, S.; Okada, T.; Maoka, T.; Kitamura, A.; Sugimoto, M.; Kume, S. Astaxanthin ameliorates heat stress-induced impairment of blastocyst development in vitro:-astaxanthin colocalization with and action on mitochondria. J. Assist. Reprod. Genet. 2013, 30, 623-631. [CrossRef]

49. Zhang, Z.W.; Xu, X.C.; Liu, T.; Yuan, S. Mitochondrion-Permeable Antioxidants to Treat ROS-Burst-Mediated Acute Diseases. Oxid. Med. Cell. Longev. 2016, 2016, 6859523. [CrossRef]

50. Park, J.S.; Mathison, B.D.; Hayek, M.G.; Zhang, J.; Reinhart, G.A.; Chew, B.P. Astaxanthin modulates age-associated mitochondrial dysfunction in healthy dogs. J. Anim. Sci. 2013, 91, 268-275. [CrossRef]

51. Baburina, Y.; Odinokova, I.; Krestinina, O. The Proapoptotic effect of melatonin on the functioning of the nonspecific mitochondrial pore (mPTP) in rat mitochondria. Neurochem. J. 2019, 13, 156-163. [CrossRef]

52. Baburina, Y.; Odinokova, I.; Azarashvili, T.; Akatov, V.; Lemasters, J.J.; Krestinina, O. 2' ,3'-Cyclic nucleotide $3^{\prime}$-phosphodiesterase as a messenger of protection of the mitochondrial function during melatonin treatment in aging. Biochim. Et Biophys. Acta Biomembr. 2017, 1859, 94-103. [CrossRef] [PubMed]

53. Wu, Y.; Shamoto-Nagai, M.; Maruyama, W.; Osawa, T.; Naoi, M. Phytochemicals prevent mitochondrial membrane permeabilization and protect SH-SY5Y cells against apoptosis induced by PK11195, a ligand for outer membrane translocator protein. J. Neural Transm. 2017, 124, 89-98. [CrossRef] [PubMed]

54. Anholt, R.R.; Pedersen, P.L.; De Souza, E.B.; Snyder, S.H. The peripheral-type benzodiazepine receptor. Localization to the mitochondrial outer membrane. J. Biol. Chem. 1986, 261, 576-583.

55. Morin, D.; Musman, J.; Pons, S.; Berdeaux, A.; Ghaleh, B. Mitochondrial translocator protein (TSPO): From physiology to cardioprotection. Biochem. Pharmacol. 2016, 105, 1-13. [CrossRef]

56. McEnery, M.W.; Snowman, A.M.; Trifiletti, R.R.; Snyder, S.H. Isolation of the mitochondrial benzodiazepine receptor: Association with the voltage-dependent anion channel and the adenine nucleotide carrier. Proc. Natl. Acad. Sci. USA 1992, 89, 3170-3174. [CrossRef]

57. Morciano, G.; Giorgi, C.; Bonora, M.; Punzetti, S.; Pavasini, R.; Wieckowski, M.R.; Campo, G.; Pinton, P. Molecular identity of the mitochondrial permeability transition pore and its role in ischemia-reperfusion injury. J. Mol. Cell. Cardiol. 2015, 78, 142-153. [CrossRef] 
58. Elrod, J.W.; Molkentin, J.D. Physiologic functions of cyclophilin D and the mitochondrial permeability transition pore. Circ. J. 2013, 77, 1111-1122. [CrossRef]

59. Basso, E.; Fante, L.; Fowlkes, J.; Petronilli, V.; Forte, M.A.; Bernardi, P. Properties of the permeability transition pore in mitochondria devoid of Cyclophilin, D. J. Biol. Chem. 2005, 280, 18558-18561. [CrossRef]

60. Giorgio, V.; Bisetto, E.; Soriano, M.E.; Dabbeni-Sala, F.; Basso, E.; Petronilli, V.; Forte, M.A.; Bernardi, P.; Lippe, G. Cyclophilin D modulates mitochondrial F0F1-ATP synthase by interacting with the lateral stalk of the complex. J. Biol. Chem. 2009, 284, 33982-33988. [CrossRef]

61. Porter, G.A., Jr.; Beutner, G. Cyclophilin D, Somehow a Master Regulator of Mitochondrial Function. Biomolecules 2018, 8, 176. [CrossRef] [PubMed]

62. Chinopoulos, C.; Adam-Vizi, V. Modulation of the mitochondrial permeability transition by cyclophilin D: Moving closer to F(0)-F(1) ATP synthase? Mitochondrion 2012, 12, 41-45. [CrossRef] [PubMed]

63. Bonora, M.; Bononi, A.; De Marchi, E.; Giorgi, C.; Lebiedzinska, M.; Marchi, S.; Patergnani, S.; Rimessi, A.; Suski, J.M.; Wojtala, A.; et al. Role of the c subunit of the FO ATP synthase in mitochondrial permeability transition. Cell Cycle 2013, 12, 674-683. [CrossRef] [PubMed]

64. Neginskaya, M.A.; Solesio, M.E.; Berezhnaya, E.V.; Amodeo, G.F.; Mnatsakanyan, N.; Jonas, E.A.; Pavlov, E.V. ATP Synthase C-Subunit-Deficient Mitochondria Have a Small Cyclosporine A-Sensitive Channel, but Lack the Permeability Transition Pore. Cell Rep. 2019, 26, 11-17. [CrossRef]

65. Tan, W.; Colombini, M. VDAC closure increases calcium ion flux. Biochim. Biophys. Acta Biomembr. 2007, 1768, 2510-2515. [CrossRef]

66. Rostovtseva, T.K.; Sheldon, K.L.; Hassanzadeh, E.; Monge, C.; Saks, V.; Bezrukov, S.M.; Sackett, D.L. Tubulin binding blocks mitochondrial voltage-dependent anion channel and regulates respiration. Proc. Natl. Acad. Sci. USA 2008, 105, 18746-18751. [CrossRef]

67. Hsu, Y.Y.; Liu, C.M.; Tsai, H.H.; Jong, Y.J.; Chen, I.J.; Lo, Y.C. KMUP-1 attenuates serum deprivation-induced neurotoxicity in SH-SY5Y cells: Roles of PKG, PI3K/Akt and Bcl-2/Bax pathways. Toxicology 2010, 268, 46-54. [CrossRef]

68. Baburina, Y.; Odinokova, I.; Azarashvili, T.; Akatov, V.; Sotnikova, L.; Krestinina, O. Possible Involvement of 2,3-Cyclic Nucleotide-3-Phosphodiesterase in the Protein Phosphorylation-Mediated Regulation of the Permeability Transition Pore. Int. J. Mol. Sci. 2018, 19, 3499. [CrossRef]

69. Zaouali, M.A.; Panisello, A.; Lopez, A.; Castro, C.; Folch, E.; Carbonell, T.; Rolo, A.; Palmeira, C.M.; Garcia-Gil, A.; Adam, R.; et al. GSK3beta and VDAC Involvement in ER Stress and Apoptosis Modulation during Orthotopic Liver Transplantation. Int. J. Mol. Sci. 2017, 18, 591. [CrossRef]

70. Bijur, G.N.; Jope, R.S. Glycogen synthase kinase-3 beta is highly activated in nuclei and mitochondria. Neuroreport 2003, 14, 2415-2419. [CrossRef]

71. Das, S.; Wong, R.; Rajapakse, N.; Murphy, E.; Steenbergen, C. Glycogen synthase kinase 3 inhibition slows mitochondrial adenine nucleotide transport and regulates voltage-dependent anion channel phosphorylation. Circ. Res. 2008, 103, 983-991. [CrossRef] [PubMed]

72. Wang, Y.L.; Zhu, X.L.; Sun, M.H.; Dang, Y.K. Effects of astaxanthin onaxonal regeneration via cAMP/PKA signaling pathway in mice with focal cerebral infarction. Eur. Rev. Med. Pharmacol. Sci. 2019, 23, 135-143. [PubMed]

73. Krestinina, O.V.; Odinokova, I.V.; Baburina, Y.L.; Azarashvili, T.S. Detection of Protein Kinase A and C Target Proteins in Rat Brain Mitochondria. Biochem. Mosc. Suppl. Ser. A Membr. Cell Biol. 2018, 12, 70-73. [CrossRef]

74. Qi, X.; Xu, J.; Wang, F.; Xiao, J. Translocator protein (18 kDa): A promising therapeutic target and diagnostic tool for cardiovascular diseases. Oxid. Med. Cell. Longev. 2012, 2012, 162934. [CrossRef]

75. Zhang, L.; Zhao, H.; Zhang, X.; Chen, L.; Zhao, X.; Bai, X.; Zhang, J. Nobiletin protects against cerebral ischemia via activating the $\mathrm{p}-\mathrm{Akt}, \mathrm{p}-\mathrm{CREB}, \mathrm{BDNF}$ and $\mathrm{Bcl}-2$ pathway and ameliorating BBB permeability in rat. Brain Res. Bull. 2013, 96, 45-53. [CrossRef]

(C) 2019 by the authors. Licensee MDPI, Basel, Switzerland. This article is an open access article distributed under the terms and conditions of the Creative Commons Attribution (CC BY) license (http://creativecommons.org/licenses/by/4.0/). 